\title{
Investigation of freshwater sponges spicules deposits in a karstic lake in Brazil
}

\author{
V. S. Machado ${ }^{*}$, C. Volkmer-Ribeiro ${ }^{b}$ and R. Iannuzzic \\ aPrograma de Pós-graduação em Geociências, Instituto de Geociências, Universidade Federal do Rio Grande do Sul - \\ UFRGS, Av. Bento Gonçalves, 9500, Prédio 43113, CEP 91501-970, Porto Alegre, RS, Brazil \\ bMuseu de Ciências Naturais - MCN, Fundação Zoobotânica do Rio Grande do Sul - FZB, CP 1188, CEP 90001-970, \\ Rua Dr. Salvador França, 1427, CEP 90690-000, Porto Alegre, RS, Brazil \\ 'Departamento de Paleontologia e Estratigrafia, Instituto de Geociências, Universidade Federal do Rio Grande do Sul - \\ UFRGS, Av. Bento Gonçalves, 9500, Prédio 43113, CEP 91501-970, Porto Alegre, RS, Brazil \\ *e-mail: biologavsm@gmail.com
}

Received: May 20, 2014 - Accepted: October 21, 2014 - Distributed: February 29, 2016

(With 3 figures)

\begin{abstract}
The environmental conditions which contributed to the formation of the notorious quaternary deposits of freshwater sponge spicules in karstic lentic environments in Brazil have been subject of some speculation. No investigation has yet been conducted to test whether these deposits currently originate in karstic lakes. To provide for such an investigation, Serra Negra Lake, which is formed on an ultramafic-alkaline-carbonatite dome at central western Brazil, close to the area of occurrence of the paleo-deposits was selected for the study. Bottom sediments were sampled at 10 stations across the lake, and water was sampled at five of the stations, in June/2011 (rainy season) and October/2011 (dry season). Analysis of granulometry, organic matter and presence of spicules were carried out in the sediments. Lake water was analysed for the main physical and chemical characteristics. Deposit of spicules was restricted to the northern area of the lake, which is rich in macrophyte. The taxonomic analysis of the spicules indicated the contribution of five sponge species, Dosilia pydanieli, Metania spinata, Radiospongilla amazonensis, Trochospongilla variabilis and Heterorotula fistula, which formed large deposits in neighbouring areas. The high silica concentration, derived from the dome volcanic rocks, constant water level and available substrate are credited for the continuous production of sponges and spicules, confirmed by the rare presence of gemmoscleres. The lake is classed as a minerotrophic fen type of bog with a heavy contribution from the surrounding creeks. Lake sediments are fine with high levels of organic matter and peat, which contributed to the trapping of spicules in the sediments.
\end{abstract}

Keywords: continental sponges spicules, bottom sediments, bogs, Cerrado Biome.

\section{Investigação de depósito de espículas de esponjas de água doce em um lago cárstico no Brasil}

\section{Resumo}

As condições ambientais que contribuíram para a formação de notórios depósitos quaternários de espículas de esponjas de água doce em ambientes cársticos no Brasil têm sido objeto de algumas especulações. Nenhuma investigação foi ainda realizada para testar se esses depósitos originam-se atualmente em lagos cársticos. Para prover tal investigação, a Lagoa Serra Negra, formada em um domo ultramáfico-alcalino-carbonatítico, no centro oeste do Brasil, próximo à área de ocorrência dos referidos paleo-depósitos, foi selecionada para o estudo. Sedimentos de fundo foram amostrados em 10 estações ao longo do lago, e a água foi coletada em cinco das estações, em junho/2011 (estação chuvosa) e outubro/2011 (estação seca). Análises de granulometria, matéria orgânica e presença de espículas foram realizadas nos sedimentos. A água do lago foi analisada para as principais características físicas e químicas. O depósito de espículas foi restrito à área norte do lago, que é rico em macrófitas. A análise taxonômica das espículas indicou a contribuição de cinco espécies de esponjas, Dosilia pydanieli, Metania spinata, Radiospongilla amazonensis, Trochospongilla variabilis e Heterorotula fistula, que formaram grandes depósitos em áreas vizinhas. A alta concentração de sílica, derivada das rochas vulcânicas do domo, o nível constante da água e a disponibilidade de substrato são creditadas à produção contínua de esponjas e espículas, confirmada pela presença rara de gemoscleras. O lago é classificado como uma turfeira do tipo fen, minerotrófica, com forte contribuição dos arroios circundantes. Os sedimentos da lagoa são finos, com altos níveis de matéria orgânica e formação de turfa, o que contribuiu para a captura das espículas nos sedimentos.

Palavras-chave: espículas de esponjas continentais, sedimentos de fundo, turfeiras, Bioma Cerrado. 


\section{Introduction}

Several worldwide studies on lentic quaternary sediments report the use of freshwater sponge spicules as a diagnostic tool in paleointerpretations (Moura, 1958; Racek, 1974; Harrison et al., 1979; Harrison and Warner, 1986). In this respect several studies have been conducted in South America (Turcq et al., 1998; Sifeddine et al., 2001; Cordeiro et al., 2008; Volkmer-Ribeiro et al., 2007; Parolin et al., 2008).

The occurrence of massive quaternary deposits of freshwater sponge spicules are economically important biomineral resources (spongillites) and raise particular interest in a large region of central-western Brazil (Volkmer-Ribeiro et al., 1998a). The study of such deposits has focused on the identification of the sponge species involved in deposit production, such as the karstic processes involved at sites of accumulation (Volkmer-Ribeiro et al., 1998a; Almeida et al., 2009, 2010; Machado et al., 2012), as well as the interpretation of the paleoenvironmental conditions of the lake during deposit formation (Volkmer-Ribeiro and Motta, 1995; Almeida et al., 2009; Machado et al., 2012). The freshwater sponge extant community identified from their spicules in such deposits was composed of Metania spinata (Carter, 1881), Dosilia pydanieli Volkmer-Ribeiro (1992), Heterorotula fistula Volkmer-Ribeiro and Motta (1995), Corvomeyenia thumi (Traxler, 1895), Radiospongilla amazonensis Volkmer-Ribeiro and Maciel (1983) and Trochospongilla variabilis Bonetto and Ezcurra de Drago (1973).

No studies have yet been conducted to determine whether spicule deposits by the same sponge community are presently taking place in karstic lakes, as well as the processes involved in the present deposit formation. Serra Negra Lake is located in the region of spongillite deposits in Brazil and was selected for this investigation. The lake is formed in a dome of carbonatitic basement rocks (Ribeiro et al., 2001). The results indicate some geomorphological and environmental conditions, which favour continued production of sponges and the trapping of their spicules in the sediment.

\section{Material and Methods}

Serra Negra Lake is located in the dome structure of the ultramafic-alkaline-carbonatite complex of Serra Negra in Patrocínio, Minas Gerais (18 ${ }^{\circ} 54^{\prime} 36.75^{\prime} \mathrm{S}$ $46^{\circ} 49^{\prime} 35.37$ ' O) (Figure 1). The lake has a surface area of approximately $5 \mathrm{~km}^{2}$ at $280 \mathrm{~m}$ above the local base level, with an altitude of $1,156 \mathrm{~m}$ in the centre of the dome structure. The geomorphological structure of the dome shows a radial centripetal drainage system that accumulates in the centre.

The areas of lower declivity, which include the south and central portions of the Serra Negra Lake, are flattened with moist soil and are covered by gramineous and hydrophilic vegetation such as Sphagnum spp. (Salgado-Labouriau, 1997), in addition to jagged small basins and channels derived from drainage flow. The confluence of three streams, Bebedouro, Bananeira and another small one at the central portion of the lake forms a network of small channels and basins with a reduced northeast/north/northwest flow. The northern portion of the lake corresponds to an area formed by small basins and channels, covered with aquatic vegetation, which surrounds a deeper area with open water at the surface.

According to Salgado-Labouriau (1997), the Serra Negra Lake is a shallow lake in a large caldera, probably due to the collapse of layers underneath. The current investigation is based on the premise that the presence of spicules in the sediments of a closed system as that of a lake placed on top of a dome would qualify as 'in situ' its sponge production.

Two expeditions to the lake were undertaken, one in May-June/2011 (fall - high-water; 30/05 to 04/06 - Authorization SISBIO $n^{\circ} 23184-3$ ) and another in October/2011 (spring - low-water; 04/10 to 08/10 - Authorization SISBIO $\left.n^{\circ} 31548-1\right)$.

Five samples from the lake bottom sediments were collected along the lake margins and at the streams (Stations 1-5; Figure 1) in each one of two expeditions. Plastic containers were plunged directly into the sediments. In the northern, open water portion of the lake, five additional samples were collected in the second expedition (Stations 6-10; Figure 1) with an Eckman dredge on board of a boat. Table 1 lists the location and description of the sampling stations as well as general characteristics of the lake sediments.

Conductivity and water temperature were measured in situ with HACH models 50150 and 50050 in both expeditions, at Stations 1-5 of sediment sampling. At the same time, water samples were collected in $1.5 \mathrm{~L}$ amber glass bottles and placed in Styrofoam boxes with ice and sent to the Division of Technical Advisory and Chemical Analysis (DIAAQ) of the Institute of Chemistry of the Federal University of Uberlândia, MG. Samples were processed to determine $\mathrm{pH}$, biochemical oxygen demand (BOD), dissolved oxygen (DO), total phosphorus, ammonia nitrogen, turbidity, alkalinity and silica (APHA, 1980).

Fractions of $0.35 \mathrm{~cm}^{3}$ from all sediments sampled in the two expeditions were processed according to Volkmer-Ribeiro (1985) for taxonomic identification and relative quantification of spicules (Abundant $=+++$; Few $=++$; rare $=+$ ) under an optical microscope. The degree of formation and fragmentation of the spicules was also recorded. Species identification was based on Volkmer-Ribeiro (1992) and Volkmer-Ribeiro and Motta (1995). Spicules corresponding to each sponge species were photographed with a Still Camera Canon PowerShot G11 coupled to an optical microscope, Leica. All sediment samples and permanent slides were catalogued in the Porifera collection of the Museum of Natural Sciences (MCN-POR) of the Zoobotanic Foundation of Rio Grande do Sul (FZB), with numbers 8759 to 8764 and 8878 to 8882 .

Sediments from stations 8 and 10 (Figure 1) were selected for analysis of particle size and organic matter content. The selection criteria were based on the abundance 


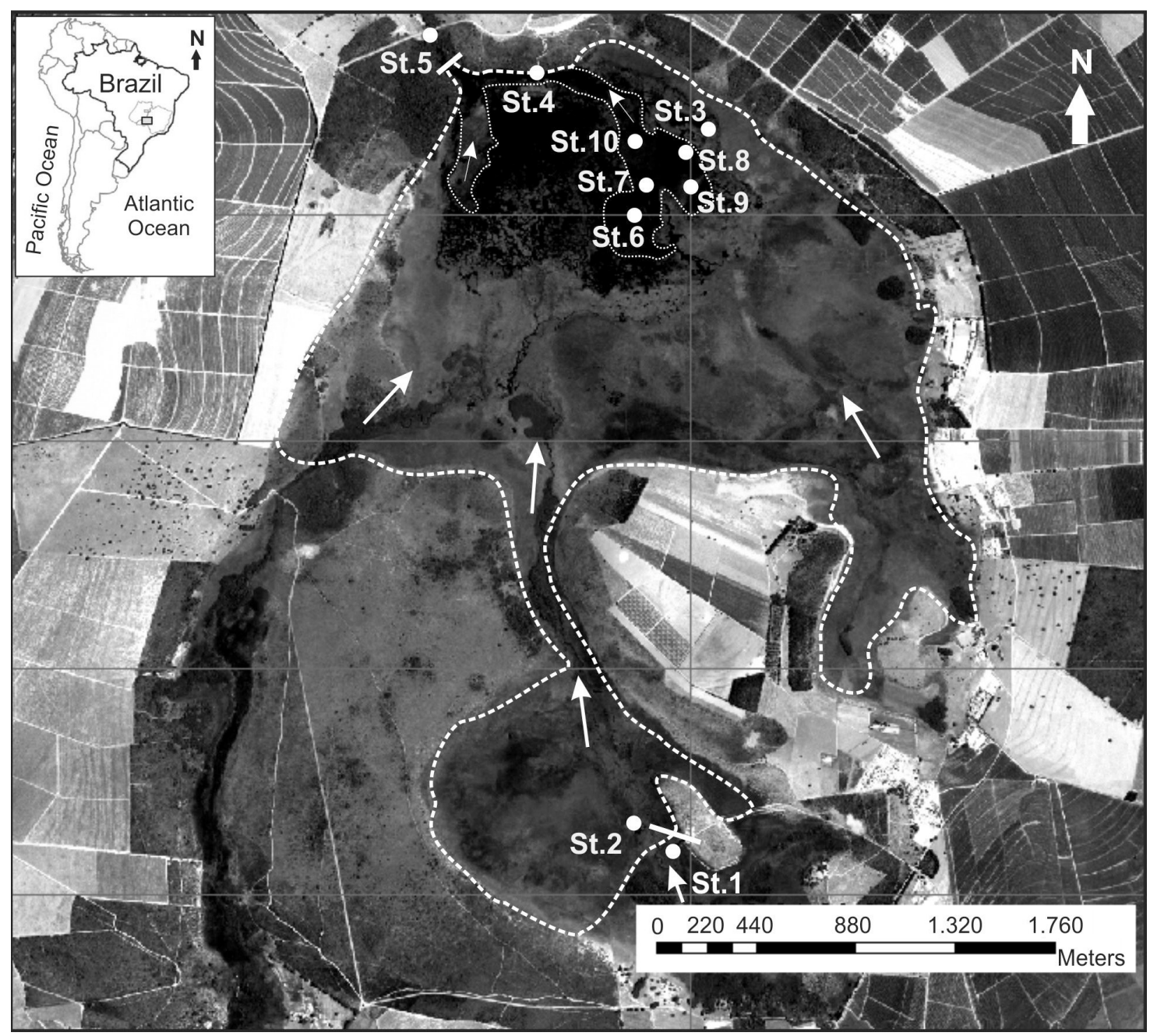

Figure 1. On the left, map showing the localization the Serra Negra Lake, in Minas Gerais, Brazil and at central, satellite image showing the lake and the distinct sampling stations (St.): St. 1, Bebedouro Stream; St. 2, Small basins; St. 3, Margin near the macrophyte stands; St. 4, Channel formed close to the lake outlet; St. 5, Small depositional basin downstream the lake outlet; St. 6-10, Central portion of the lake covered with free water. The dashed line indicates the lake borders, and the thinner line indicates the borders of the free water surface. The arrows indicate the water flow in the lake.

of spicules, type of sediment and distance to the macrophyte stands, as this substrate was the only available to the sponges. The analyses were performed at the Center for Coastal and Oceanic Geological Studies of the Federal University of Rio Grande do Sul (CECO-IG-UFRGS). The coarse sediments were separated using a set of $1 \mathrm{~mm}$ Ø sieves (Wentworth, 1922; Krumbein, 1934). For fine sediments, a liquid medium sedimentation method was used (Krumbein and Pettijohn, 1938). Organic matter content of the fine sediments was determined by the combustion method (Wetzel, 1975).

\section{Results}

The analysis of the spicules in the sediments sampled in the two expeditions showed similar results (Table 1). The accumulation of sponge spicules is currently taking place at the northern portion of the lake (Sts.3 and 6-10;
Figure 1). Fully formed and well preserved megascleres and microscleres (spicules from skeleton) were dominant (Figures $2 \mathrm{a}$ and $2 \mathrm{~b}$ ). However, gemmoscleres (spicules from gemmules) were rare. Dosilia pydanieli was identified from its abundant microscleres (Figure 2b). Gemmoscleres were scarce but enabled the positive identification of Metania spinata (Figure 2c), Trochospongilla variabilis (Figure 2d), Radiospongilla amazonensis (Figure 2e) and Heterorotula fistula (Figures 2f, $2 \mathrm{~g}$ and $2 \mathrm{~h}$ ). These results indicate the existence of an extant community of sponges in Serra Negra Lake, established in the marginal area formed by small basins and channels with abundant aquatic vegetation, as detected in St. 3. The degrading sponges and their spicules accumulated under the marginal macrophytes are next dragged into the deepest area of the lake by runoff waters from the higher areas what explains the concentration of spicules in this site (Sts. 6-10; Table 1). 
Table 1. Location and description of the sampling stations (St.) in the Serra Negra Lake and respective streams, Patrocínio, $\mathrm{MG}$, are presented together with the results of the analysis of preservation conditions of the spicules, their relative total amount, their taxonomic identification and the relative amount of each spicule category in the sampled sediments.

\begin{tabular}{|c|c|c|c|}
\hline St. & Description & $\begin{array}{c}\text { Relative amount and } \\
\text { preservation conditions } \\
\text { of the spicules }\end{array}$ & $\begin{array}{c}\text { Taxonomic analysis and relative quantification } \\
\text { of each spicule category }\end{array}$ \\
\hline
\end{tabular}

Bebedouro stream. Channel

with unidirectional little

flow, dammed close to

1 the lake and with scarce macrophytic vegetation. Dark-coloured sediment with fine granulometry.

Southern part of the lake.

Small basin of anthropic

2 excavations with free water. Dark-coloured sediment

Rare, incipiently formed and fragmented spicules with fine granulometry.

Marginal point located in the central/northern part of the lake. Area formed by small basins and channels

3 and covered with aquatic

Rare, incipiently formed and fragmented spicules

vegetation, which surrounds formed and entire spicules a deeper area with free water surface. Dark-

D. pydanieli: $\mathrm{m}(+++)$; $\mathrm{mi}(+++)$; gm $(+)$

M. spinata: am $(+++)$; bm $(++)$; $\mathrm{mi}(++)$; gm $(+)$

T. variabilis: $\mathrm{m}(+++)$; $\mathrm{gm}(+)$

R. amazonensis: $\mathrm{m}(+++)$; gm $(+)$

H. fistula: $\mathrm{m}(+++)$; lgm $(+)$; $\operatorname{sgm}(+)$

coloured sediment with fine

granulometry.

Channel at the northern

border, taking to the lake

outlet. Dark-coloured

4 sediment with large amount

of sand and presence of

Few, completely formed and entire spicules
D. pydanieli: $\mathrm{m}(++)$; $\mathrm{mi}(++)$

M. spinata: am $(++)$; $\mathrm{mi}(++)$

R. amazonensis: $\mathrm{m}(+++)$; gm $(+)$ millimetric to centimetric clasts.

Microbasin of sedimentation formed along the course of the stream of the outlet of the lake.

Dark-coloured sediment with great amount of sand.

Few, completely formed, but fragmented spicules

O. navicella: $\mathrm{m}(++)$; gm $(+)$

Presence of millimetric to centimetric clasts.

Central/northern portion of the Serra Negra Lake, with larger area of free water. Black sediments with gelatinous aspect and presence of vegetal fragments still not decomposed.

$\mathrm{M}=$ megasclere; $\mathrm{am}$ = alpha megasclere; $\mathrm{bm}=$ beta megasclere; $\mathrm{mi}=$ microsclere; $\mathrm{gm}$ = gemmosclere; lgm = long gemosclere $\operatorname{sgm}=$ short gemmosclere; Abundant $=+++$; Few $=++$; rare $=+$.

The occurrence of rare, incipiently formed and fragmented spicules in sediments of St. 1 and 2 prevented their taxonomic identification (Table 1). Only spicules of Oncosclera navicella (Carter, 1881), a sponge from lotic environments, were observed in sediments from St. 5
(Table 1). The presence of spicules completely formed and entire in St. 4 is credited to its location, downstream the Sts. 3, 6-10 (Figure 1).

The sediments from the northern area of Serra Negra Lake (St. 8 ) are composed by $29.5 \%$ of clay, $70 \%$ of silt, 


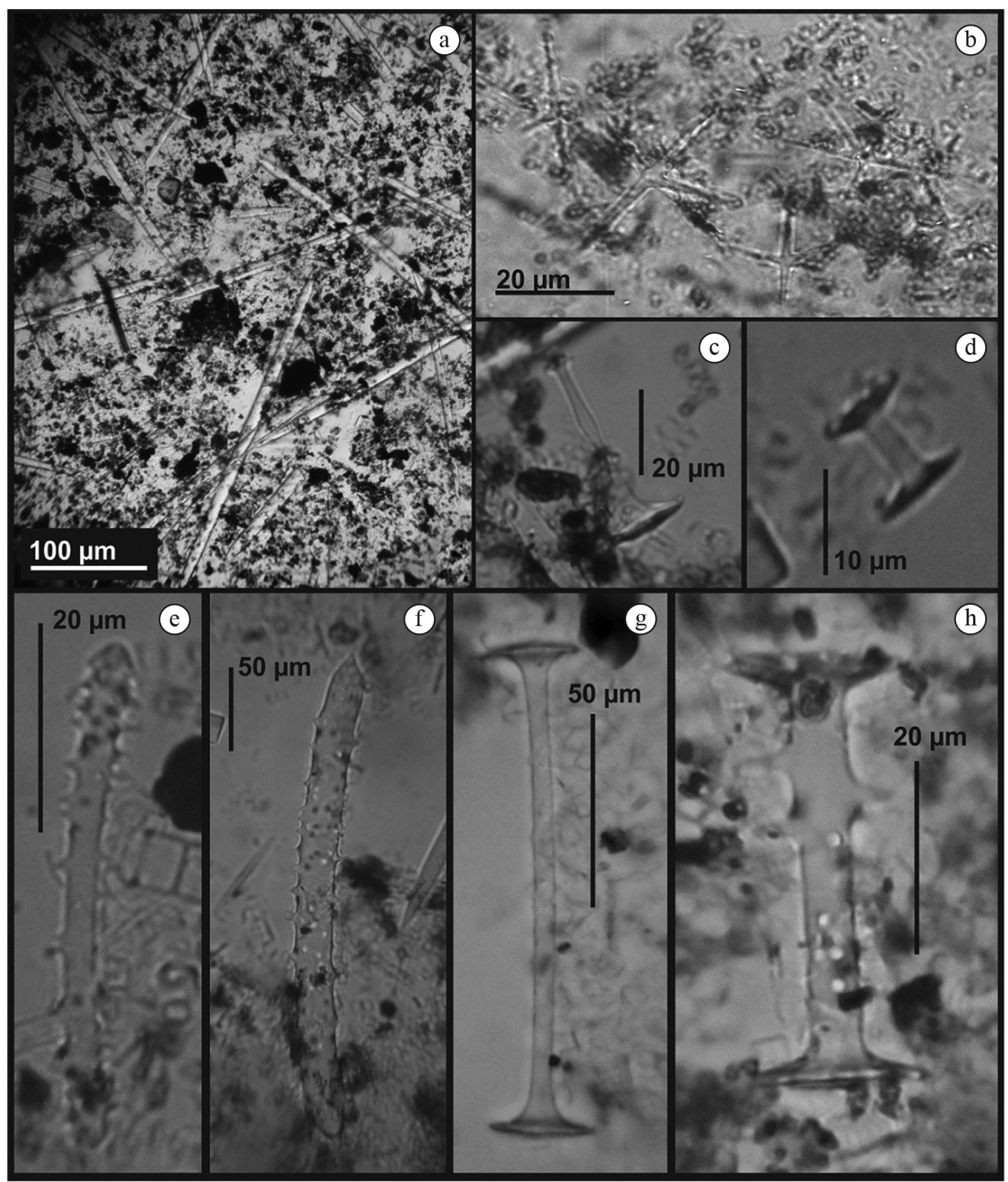

Figure 2. Optical Microscope pictures of the spicules of the six species of sponges found in the sediments of the Serra Negra Lake. a. megascleres, b. microscleres (Dosilia pydanieli Volkmer-Ribeiro, 1992); c. gemmosclere (Metania spinata (Carter, 1881)); d. gemmosclere (Trochospongilla variabilis Bonetto and Ezcurra de Drago, 1973); e. gemmosclere (Radiospongilla amazonensis Volkmer-Ribeiro and Maciel, 1983); f. megasclere, g. long gemmosclere, h. short gemmosclere (Heterorotula fistula Volkmer-Ribeiro and Motta, 1995).

$0.5 \%$ of sand and $33.60 \%$ of organic matter $(\mathrm{OM})$ and those from St. 10 are composed by $21.96 \%$ of clay, $78 \%$ of silt, $0.04 \%$ of sand and $31.60 \%$ of organic matter (OM). These sediments are classed as fine with high levels of organic matter and peat formation. The gelatinous aspect and the presence of intact vegetal fragments in the sediments of the northern area (Sts. 3 and 6-10, Table 1) confirm organic accumulation in the lake bottom. The presence of fine sediments with a dark colour at St. 1 and St. 2 (Table 1) indicates that the southern area of Serra Negra Lake also includes a peaty area. In contrast, the presence of coarser sediments at St. 4 and St. 5 (Table 1) indicates the presence of water flow, inhibiting organic accumulation.

The physical and chemical parameters of the lake and streams detected during the two studied periods are presented in Table 2 and Figure 3. The low alkalinity in 
Table 2. Physical and chemical parameters of water of Serra Negra Lake, Patrocínio, MG, sampled during the two seasonal periods at the five sampling stations (St.).

\begin{tabular}{|c|c|c|c|c|c|c|c|c|c|c|}
\hline \multirow{2}{*}{ Parameters } & \multicolumn{5}{|c|}{ June/2011 (high water) } & \multicolumn{5}{|c|}{ October/2011 (low water) } \\
\hline & St. 1 & St. 2 & St. 3 & St. 4 & St. 5 & St. 1 & St. 2 & St. 3 & St. 4 & St. 5 \\
\hline Cond. & 8 & 9 & 5 & 18 & 10 & 11 & 9 & 6 & 21 & 13 \\
\hline $\mathrm{pH}$ & 5.73 & 5.65 & 5.6 & 6.38 & 6.23 & 5.32 & 5.82 & 5.7 & 6.13 & 6.09 \\
\hline Turbid. & 7.8 & 6.9 & 6.5 & 18 & 7.3 & 11 & 25 & 7 & 13 & 9 \\
\hline Silica & 17 & 13 & 8 & 23 & 11 & 25 & 32 & 13 & 21 & 17 \\
\hline Alkal. & 4.1 & 2.5 & 4.4 & 4 & 6 & 4.78 & 5.2 & 4.18 & 5.18 & 6.76 \\
\hline $\mathrm{DO}$ & 5.4 & 5 & 5 & 4.6 & 4.8 & 5.2 & 4.8 & 5 & 5.2 & 5.7 \\
\hline BOD & 13 & 10 & 11 & 21 & 8 & 11 & 21 & 9 & 14 & 6 \\
\hline Temp. & 18 & 17 & 22 & 21 & 19 & 20 & 19 & 25 & 20 & 19 \\
\hline Phosp. & 0.009 & 0.013 & 0.008 & 0.16 & 0.005 & 0.008 & 0.013 & 0.005 & 0.006 & 0.002 \\
\hline AmmNitrog & 0.31 & 0.25 & 0.32 & 0.51 & 0.19 & 0.2 & 0.45 & 0.15 & 0.4 & 0.13 \\
\hline OrgNitrog & 0.1 & 0.07 & 0.2 & 0.13 & 0.09 & 0.06 & 0.3 & 0.07 & 0.19 & 0.05 \\
\hline Depth & 1.2 & 1.0 & 1.1 & 1.5 & 1.0 & 1.05 & 0.8 & 0.7 & 0.8 & 1.0 \\
\hline
\end{tabular}

Cond.: Conductivity (uS); pH: Hydrogen potential; Turbid.: Turbidity (U.N.T.); Silica: Dissolved silica (mg/L); Alkal.: Alkalinity $(\mathrm{mg} / \mathrm{L})$; DO: Dissolved oxygen (mg/L); BDO: Biochemical oxygen demand (mg/L); Temp.: Temperature $\left({ }^{\circ} \mathrm{C}\right)$; Phosp.: Phosphorus (mg/L); AmmNitrog.: Ammoniacal nitrogen (mg/L); OrgNitrog.: Organic nitrogen (mg/L); Depth (m).

all sampled stations and in the two periods evidences the low buffering capacity of this lake, also indicated by a slightly acidic $\mathrm{pH}$ (5.32-6.38; Table 2). All sampling sites had higher values of biochemical oxygen demand (BOD) compared to dissolved oxygen (DO), pointing to an environment with relatively low capacity to degrade the organic matter by aerobic biological processes. These results also indicate that accumulation of humic acids prevails even under the influence of the alkaline rocks present in the dome.

Values of conductivity, turbidity, silica and BOD were the sole to show significant differences among the sampled stations (Figure 3). The lowerest values for these parameters were observed in St. 3 and the highest in St. 4. Higher values for conductivity, turbidity and silica and reduced BOD characterize the low water period. St. 2 is remarkable for its increasing values of turbidity, silica and $\mathrm{BDO}$ in the low water period, reflecting the reduced flow and the respective accumulation of organic debris at this site. St. 1 and St. 5 which stand for respectively the in and out water fluxes at the Serra Negra System, show water quality which reflects the peat accumulation. At St. 1 the process is credited to the lower water flux induced by the damming of the water at this site (Figure 1).

\section{Discussion}

The physical and chemical analysis of Serra Negra Lake water is characteristic of peat water. Peat waters have been previously characterized for both bog and fens environments. According to Breemen (1995), bogs are formed in elevated areas and with a $\mathrm{pH}<4.2$, whilst fens are set in concave or flat areas and have a surface water
$\mathrm{pH}>4.2$. The characteristic vegetation of fens, according to Shotyk (1988), consists of grasses and some varieties of Sphagnum spp. Typical fen vegetation characteristics are observed at Serra Negra Lake and were previously described by Salgado-Labouriau (1997). Bogs are distinguished by the dominance of Sphagnum spp. (Moore, 1989). Shotyk (1988) also include hydrological parameters to distinguish peat bogs fed exclusively by precipitation water (rain and/or snow), called ombrotrophic bogs and those influenced by water from the external limits of the basin are called minerotrophic bogs. As Serra Negra Lake is subject to periodic flooding by runoff from the adjacent dome and streams, it could be classified as a minerotrophic bog. A study of the physical and chemical characteristics of water from bogs, swamps and fens of northern Michigan found significant differences between bogs and fens but not between fens and swamps (Schwintzer and Tomberlin, 1982). According to these authors the fens/swamps are moderately minerotrophic ( $\mathrm{pH}$ varying from 5.5 to 7.4), whereas bogs are poorly minerotrophic ( $\mathrm{pH}$ varying from 3.8 to 4.4 ), which indicates a difference in the hydrological regime, with a greater flow of water in fens/swamps. Schwintzer and Tomberlin (1982) also found differences in the chemical constituents of fen waters with values from moderate to high for calcium, magnesium, silica, alkalinity and conductivity and low values for sodium, phosphorus, nitrogen and potassium. Serra Negra Lake $\mathrm{pH}$, silica, phosphorus and nitrogen (Table 2) obtained in the two expeditions of this study are comparable to the fens of Schwintzer and Tomberlin (1982), but are lower in alkalinity and conductivity, which makes the environment more similar to a bog. Therefore, Serra Negra Lake can be considered moderately minerotrophic given 

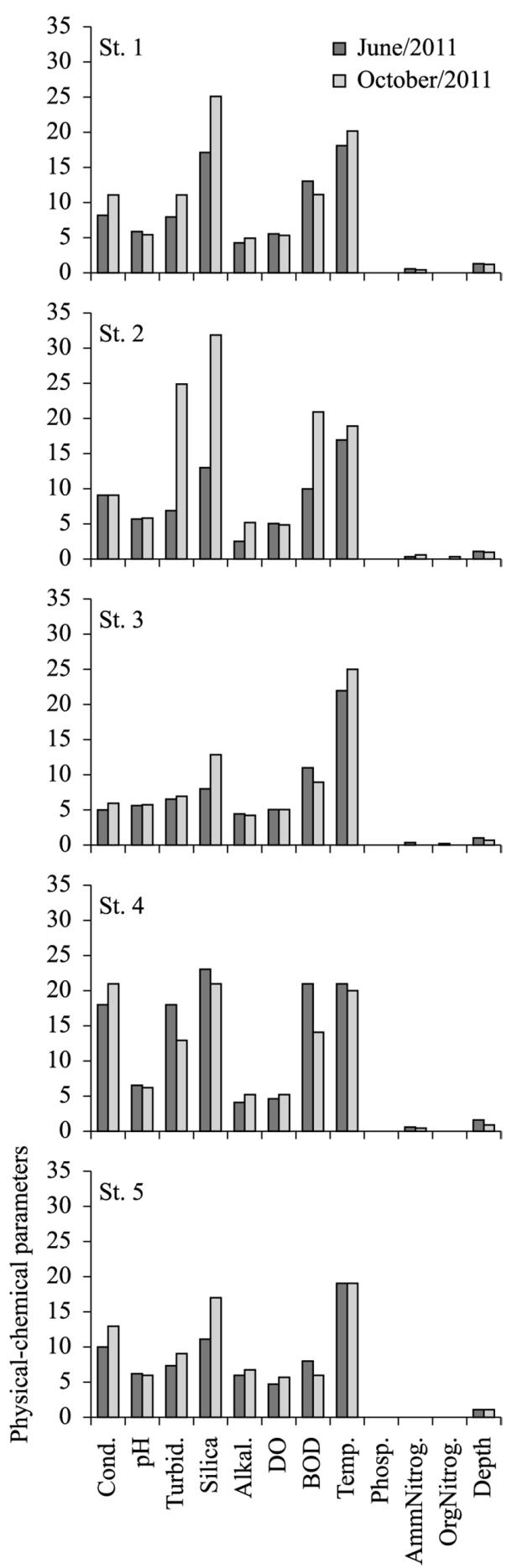

Figure 3. Graph showing the variation of the physical and chemical parameters at Stations 1-5 (St.) in Serra Negra Lake and streams during the two studied periods (Cond.: Conductivity (uS); pH: Hydrogen potential; Turbid.: Turbidity (U.N.T.); Silica: Dissolved silica (mg/L); Alkal.: Alkalinity (mg/L); DO: Dissolved oxygen (mg/L); BDO: Biochemical oxygen demand (mg/L); Temp.: Temperature $\left({ }^{\circ} \mathrm{C}\right)$; Phosp.: Phosphorus (mg/L); AmmNitrog.: Ammoniacal nitrogen (mg/L); OrgNitrog.: Organic nitrogen $(\mathrm{mg} / \mathrm{L})$; Depth (m)). the influence of considerable flow, and the physical and chemical characteristics of the lake make it more similar to a fen. The difference in conductivity, turbidity, silica and BOD between stations 3 and 4 (Figure 3) indicates a larger water flux towards the lake outlet (Figure 1), based on the presence of $O$. navicella in St. 5 (Table 1), an species with a marked preference for lotic habitats (Volkmer-Ribeiro and Pauls, 2000).

The development of a high biomass of aquatic vegetation in the central/northern part of the Lake (St.3; Table 1) was fundamental for the recent formation of spicule deposits in Serra Negra Lake. Esteves and Caliman (2011) suggest that the occurrence of this vegetation is dependent on the morphometric characteristics of the lake environment, such as depth. These authors hypothesize that shallow aquatic ecosystems (up to $2 \mathrm{~m}$ deep), where the limnetic region is reduced or nonexistent, may have most or all lake area covered by macrophytes. Serra Negra Lake is a shallow lake not exceeding $2 \mathrm{~m}$ (Table 1), allowing the colonisation of dense marginal aquatic vegetation including microalgae, bryophytes, pteridophytes and superior plants, providing abundant substrate for sessile organisms. Colonisation by aquatic vegetation leading to the eventual establishment of peat constitutes a favourable environment for some sponges, as demonstrated by Frost (1991), Volkmer-Ribeiro (1992) and Volkmer-Ribeiro et al. (1998b).

The continental sponges detected in the Serra Negra Lake indicate the presence of a community typical of lakes in the Cerrado biome, as reported by Volkmer-Ribeiro (1999). The Cerrado Biome contains a large array of natural lakes, where the water level depends on the precipitation. Usually a reduction of water level occurs in the dry period and recovery in the rainy season (Fonseca, 2005). The Cerrado Biome lakes are located in flat areas and fed by groundwater, while Serra Negra Lake, which is located in the Cerrado Biome, but formed on a dome of igneous rocks sits at an altitude of approximately 1,000 m. Marcuzzo et al. (2012) found that the seasonal and spatial variation of the rainfall in the Cerrado of Mato Grosso do Sul, show higher pluviometric levels at higher altitudes. The Rainfall Anomaly Index (RAI) supplied by the authors indicate that in the last 30 years the region experienced $30.56 \%$ dry months, $25.83 \%$ rainy months, $22.22 \%$ very dry months, $10.56 \%$ very rainy months and less than $10 \%$ extremely dry, extremely rainy months as well as months without anomalies. These authors also remark that between 1997 and 2006, the number of extremely rainy months was 19 and the number of extremely dry months was 13. Given that the Serra Negra dome is not far from the region studied by Marcuzzo et al. (2012), we may infer that the high altitude of Serra Negra Lake may have similar microclimate conditions, such as higher pluviometric levels and reduced periods of extreme drought. This may result in higher water residence, even in lower pluviometric periods. In addition, Serra Negra Lake is artificially dammed at the outlet, which may also contribute to longer water residence. Gemmules are asexual reproduction structures of continental sponges produced 
in dry and otherwise adverse periods of the year (Frost, 1991; Volkmer-Ribeiro and Pauls, 2000). The rarity of gemmoscleres in the bottom sediments of the Serra Negra Lake provides additional evidence for the perennial nature of this lake, which would favour continuous production of sponges and spicules.

The sponge community found in this study, without H. fistula and the addition of Corvomeyenia thumi (Traxler, 1895), was reported in a seasonal lake on Maracá Island, Roraima (Volkmer-Ribeiro, 1992; Volkmer-Ribeiro et al., 1998b). Volkmer-Ribeiro et al. (op cit.) consider that the environment of Maracá Island, containing small lakes that do not exceed $2 \mathrm{~m}$ in depth in the rainy season, and those that dry out at the peak of dry season are a transitional environment between the Amazon Forest and the Cerrado Biome. Maracá Lake is approximately $200 \mathrm{~m}$ in diameter and is surrounded by a dense forest that ends at the lake margins with a circle of Buriti palm trees. Abundant aquatic vegetation occupies the lake, restricting the open water area to the lake centre and produces a large biomass of decomposing vegetation in the dry season. Volkmer-Ribeiro (1992) mentions the abundant presence of gemmules in all the collected sponge specimens, in this seasonal environment. The rarity of gemmoscleres in the bottom sediments of the Serra Negra Lake, as well as the absence of $C$. thumi, a sponge typical of environments subjected to severe droughts indicates the perennial nature of this lake, which differentiates it from the seasonal Maracá Lake. Nevertheless, some similarities in the chemical constituents of the water were noted for these two environments. The $\mathrm{pH}$ (5.46 and 5.36) of Maracá Lake (Volkmer-Ribeiro et al., 1998b) is similar to the $\mathrm{pH}$ of Serra Negra Lake. Conductivity is lower in Maracá Lake, however, it can be considered low in both lakes. Dissolved oxygen, phosphorus and nitrogen were lower in the Serra Negra Lake samples, which may be related to the presence of peat and its high absorption and cation exchange capacity (Coupal and Lalancette, 1976). Peat may act as a trap for sponge spicules, which become integrated and retained in lake sediments.

Volkmer-Ribeiro et al. (1998b) attribute the absence of peat and spicule deposits at the bottom of Lake in Maracá to a lower input of silica to the lake water because of the surrounding forestall covering of the area. The authors credit the abundance of sponges and corresponding gemmules to a seasonal remobilisation of silica fixed by the sponges and macrophytic vegetation of the previous season.

Silica is important in the formation of sponge spicules (Jorgensen, 1944). In the current study, dissolved silica in Serra Negra Lake varied from 8 to $32 \mathrm{mg} / \mathrm{L}$ (Table 2), which is considerably higher than that recorded by Volkmer-Ribeiro et al. (1998b) in Maracá Lake (2.2 mg/L). The high dissolved silica concentration is likely caused by the influence of the dome volcanic rocks. Barbosa et al. (2012) report that the volcanic rocks of this ultramafic-alkaline-carbonatite complex are rich in silicate minerals.

Thus, the karstic process, which led to the formation of the Serra Negra Lake produced a singular basin with differentiated environmental characteristics, in particular for substrate, depth, water residence, peat, water flow and silica concentrations, compared to surrounding lake environments, as well as differences in the sponge community. The present paper is refered in Machado et al. (2014) as unpublished.

\section{Acknowledgements}

V. S. Machado acknowledges the Brazilian Research Council 'Conselho Nacional de Desenvolvimento Científico e Tecnológico’ (CNPq) for the Ph.D. scholarship. C. Volkmer-Ribeiro acknowledges CNPq. For granting of the Universal Project (Process 481555/2009). R. Iannuzzi acknowledges CNPq for research fellowship granted (Process PQ305687/2010-7 and PQ309211/2013-1). The authors acknowledge the Vale Fértil for logistic support during the field work, as well as permission to use the satellite image of Figure 1. The authors are indebted to the two anonymous referees for valuable suggestions which enriched this paper.

\section{References}

ALMEIDA, A.C.S., VARAJÃO, A.F.D.C., GOMES, N.S., VARAJÃO, C.A.C. and VOLKMER-RIBEIRO, C., 2010. Characterization and origin of spongillite-hosting sediment from João Pinheiro, Minas Gerais, Brazil. Journal of South American Earth Sciences, vol. 29, no. 2, pp. 439-453. http://dx.doi.org/10.1016/j.jsames.2009.09.006.

ALMEIDA, A.C.S., VOLKMER-RIBEIRO, C., VARAJÃO, A.F.D.C., GOMES, N.S. and VARAJÃO, C.A.C., 2009. Espículas de esponjas continentais nos sedimentos Cenozóicos do noroeste de Minas Gerais, como indicadores paleoambientais. Revista Brasileira de Paleontologia, vol. 12, no. 2, pp. 123-138. http:// dx.doi.org/10.4072/rbp.2009.2.03.

AMERICAN PUBLIC HEALTH ASSOCIATION -APHA, 1980. Standard methods for the examination of water and wastewater. 15th ed. Washington: APHA. $1134 \mathrm{p}$.

BARBOSA, E.S.R., BROD, J.A., JUNQUEIRA-BROD, T.C., DANTAS, E.L., CORDEIRO, P.F.O. and GOMIDE, C.S., 2012. Bebedourite from its type area (Salitre I complex): a key petrogenetic series in the Late-Cretaceous Alto Paranaíba kamafugite-carbonatite-phoscorite association, Central Brazil. Lithos, vol. 144/145, pp. 56-72. http://dx.doi.org/10.1016/j. lithos.2012.04.013.

BREEMEN, V.N., 1995. How Sphagnum bogs down other plants. Trends in Ecology \& Evolution, vol. 10, no. 7, pp. 270-275. http:// dx.doi.org/10.1016/0169-5347(95)90007-1. PMid:21237035.

CORDEIRO, R.C., TURCQ, B., SUGUIO, K., SILVA, A.O., SIFEDDINE, A. and VOLKMER-RIBEIRO, C., 2008. Holocene fires in East Amazonia (Carajás), new evidences, chronology and relation with paleoclimate. Global and Planetary Change, vol. 61, no. 1-2, pp. 49-62. http://dx.doi.org/10.1016/j.gloplacha.2007.08.005.

COUPAL, B. and LALANCETTE, J.M., 1976. The treatment of wastewaters with peat moss. Water Research, vol. 10, no. 12, pp. 1071-1076. http://dx.doi.org/10.1016/0043-1354(76)90038-5.

ESTEVES, F.A. and CALIMAN, A., 2011. Águas continentais: características do meio, compartimentos e suas comunidades. In: F.A. ESTEVES, ed. Fundamentos de limnologia. Rio de Janeiro: Interciência, pp. 113-118. 
FONSECA, C.P., 2005. Caracterização dos ecossistemas aquáticos do Cerrado. In: A. SCARIOT, J.C. SOUSA-SILVA and J.M. FELFINI, eds. Cerrado: ecologia, biodiversidade e conservação. Brasília: Ministério do Meio Ambiente, pp. 416-429.

FROST, T.M., 1991. Porifera. In: J.H. THORPY and A.P. COVICH, eds. Ecology and classification of North American freshwater invertebrates. New York: Academic Press, pp. 95-124.

HARRISON, F.W. and WARNER, B.G., 1986. Fossil freshwater sponges (Porifera: Spongillidae) from Western Canada: an overlooked group of quaternary paleoecological indicators. Transactions of the American Microscopical Society, vol. 105, no. 2, pp. 110-120. http://dx.doi.org/10.2307/3226383.

HARRISON, F.W., GLEASON, P.J. and STONE, P.A., 1979. Paleolimnology of Lake Okeechobee, Florida: an analysis utilizing spicular components of freshwater sponges (Porifera: Spongillidae). Notulae Naturae of the Academy of Natural Sciences of Philadelphia, vol. 454, pp. 1-6.

JORGENSEN, C.B., 1944. On the spicule formation of Spongilla lacustris (L.). I. The dependence of the spicule- formation on the content for dissolved and solid silicic acid of the milieu. Det Kongelige Danske Videnskabernes Selskab, Biologiske Meddelelser, vol. 19 , no. 7 , pp. 1-45.

KRUMBEIN, W.C. and PETTIJOHN, F.J., 1938. Manual of sedimentary petrography. New York: Appleton Century Crofts. 549 p.

KRUMBEIN, W.C., 1934. Size frequency distribution of sediments. Journal of Sedimentary Petrology, vol. 4, no. 2, pp. 65-77.

MACHADO, V.S., VOLKMER-RIBEIRO, C. and IANNUZZI, R., 2014. Late pleistocene climatic changes in Central Brazil indicated by freshwater sponges. International Journal of Geosciences, vol. 5, no. 8, pp. 799-815. http://dx.doi.org/10.4236/ijg.2014.58071.

MACHADO, V.S., VOLKMER-RIBEIRO, C. and IANNUZZI, R., 2012. Inventory of the sponge fauna of the Cemitério Paleolake, Catalão, Goiás, Brazil. Anais da Academia Brasileira de Ciências, vol. 84, no. 1, pp. 17-34. http://dx.doi.org/10.1590/ S0001-37652012000100004. PMid:22441593.

MARCUZZO, F.F.N., MELO, D.C.R. and COSTA, H.C., 2012. Sazonalidade e distribuição espaço-temporal das chuvas no bioma do Cerrado do Estado do Mato Grosso do Sul. Revista Brasileira de Recursos Hídricos, vol. 17, no. 1, pp. 77-86.

MOORE, P.D., 1989. The ecology of peat forming processes: a review. International Journal of Coal Geology, vol. 12, no. 1-4, pp. 89-103. http://dx.doi.org/10.1016/0166-5162(89)90048-7.

MOURA, A., 1958. Espongilideos fósseis no diatomito de Azenha do Vale de Atela (Alpiarça). Memórias e Notícias, vol. 46, pp. 23-33.

PAROLIN, M., VOLKMER-RIBEIRO, C. and STEVAUX, J.C., 2008. Use of Spongofacies as a proxy for river-lake paleohydrology in Quaternary deposits of central-western Brazil. Revista Brasileira de Paleontologia, vol. 11, no. 3, pp. 187-198. http://dx.doi. org/10.4072/rbp.2008.3.05

RACEK, A.A., 1974. The waters of Merom: a study of Lake Huley. IV. Spicular remains of fresh-water sponges (Porifera). Archiv für Hydrobiologie, vol. 74, no. 2, pp. 137-158.

RIBEIRO, C.C., BROD, J.A., JUNQUEIRA-ABROD, T.C., GASPAR, J.C. and PETRINOVIC, I.A., 2001. Pipes de brecha e atividade magmática explosiva no Complexo Alcalino-carbonatítico de Catalão I, Goiás. Revista Brasileira de Geociencias, vol. 31, no. 4 , pp. 417-426.
SALGADO-LABOURIAU, M.L., 1997. Late Quaternary palaeoclimate in the savannas of South America. Journal of Quaternary Science, vol. 12, no. 5, pp. 371-379. http://dx.doi. org/10.1002/(SICI)1099-1417(199709/10)12:5<371::AIDJQS320>3.0.CO;2-3.

SCHWINTZER, C.R. and TOMBERLIN, T.J., 1982. Chemical and physical characteristics of shallow ground waters in northern Michigan bogs, swamps, and fens. American Journal of Botany, vol. 69, no. 8, pp. 1231-1239. http://dx.doi.org/10.2307/2442747.

SHOTYK, W., 1988. Review of the inorganic geochemistry of peats and peatland water. Earth-Science Reviews, vol. 25, no. 2, pp. 95-176. http://dx.doi.org/10.1016/0012-8252(88)90067-0.

SIFEDDINE, A., MARTIN, L., TURCQ, B., VOLKMERRIBEIRO, C., SOUBIÈS, F., CORDEIRO, R.C. and SUGUIO, K., 2001. Variations of the Amazonian rainforest environment: a sedimentological record covering 30,000 years. Palaeogeography, Palaeoclimatology, Palaeoecology, vol. 168, no. 3-4, pp. 221-235. http://dx.doi.org/10.1016/S0031-0182(00)00256-X

TURCQ, B., SIFEDDINE, A., MARTÍN, L., ABSY, M.L., SOUBIÈS, F., SOUGUIO, K. and VOLKMER-RIBEIRO, C., 1998. Amazon Forest fires: a lacustrine report of 7.000 years. Ambio, vol. 27, no. 2, pp. 139-142.

VOLKMER-RIBEIRO, C. and MOTTA, J.F.M., 1995. Esponjas formadoras de espongilitos em lagoas no Triângulo Mineiro e adjacências, com indicação de preservação de habitat. Biociências, vol. 3, no. 2, pp. 145-169

VOLKMER-RIBEIRO, C. and PAULS, S.M., 2000. Esponjas de água dulce (Porífera: Demospongiae) de Venezuela. Acta Biológica Venezuelana, vol. 20, no. 1, pp. 1-28.

VOLKMER-RIBEIRO, C., 1985. Manual de técnicas para a preparação de coleções zoológicas. São Paulo: Sociedade Brasileira de Zoologia. 6 p. vol. 3.

VOLKMER-RIBEIRO, C., 1992. The freshwater sponges in some peat-bog ponds in Brazil. Amazoniana, vol. 12, no. 2, pp. 317-335.

VOLKMER-RIBEIRO, C., 1999. Esponjas. In: C.A. JOLY and C.E.M. BICUDO, eds. Biodiversidade do Estado de São Paulo, Brasil: síntese do conhecimento ao final do século XX. São Paulo: Fundação de Amparo à Pesquisa do Estado de São Paulo, pp. 1-9. Invertebrados de Água Doce, vol. 4.

VOLKMER-RIBEIRO, C., EZCURRA DE DRAGO, I. and PAROLIN, M., 2007. Spicules of the freshwater sponge Ephydatia facunda indicate lagoonal paleoenvironment at the pampas of Buenos Aires Province, Argentina. Journal of Coastal Research, vol. 50, pp. 449-452.

VOLKMER-RIBEIRO, C., MOTTA, J.F.M. and CALLEGARO, V.L.M., 1998a. Taxonomy and distribution of Brazilian Spongillites. In: Y. WANABE and N. FUSETANI, eds. Sponge sciences. Tokyo: Springer-Verlag, pp. 271-278.

VOLKMER-RIBEIRO, C. and MANSUR, M.C.D., MERA P.A.S. and ROSS, S.M., 1998b. Biological indicators in the aquatic habitats of the Ilha de Maracá. In: W. MILLIKEN and J. RATTER, eds. Maracá: the biodiversity and environment of an Amazonian rainforest. Chichester: John Wiley \& Sons, pp. 403-414.

WENTWORTH, C.K., 1922. A scale of grade and class term for clastic sediments. The Journal of Geology, vol. 30, no. 5, pp. 377-392. http://dx.doi.org/10.1086/622910.

WETZEL, R.G., 1975. Limnology. Philadelphia: W. B. Sauders Company. 743 p. 